\title{
SHELF LIFE AND QUALITY OF GUAVA CV. KAZI AS AFFECTED BY STAGES OF RIPENING, STORAGE TEMPERATURE AND WRAPPING MATERIALS
}

\author{
F. Islam ${ }^{1}$, A. Islam ${ }^{2}$, M. A. Z. Al Munsur ${ }^{3}$ and M. A. Rahim \\ Department of Horticulture, Bangladesh Agricultural University \\ Mymensingh-2202, Bangladesh
}

\begin{abstract}
The experiment was conducted to study the shelf life and quality as affected by different stages of ripening, storage temperature as well as wrapping materials fruits of guava cv. Kazi. All the studied parameters except marketability increased for a certain storage period and then declined due to the effect of stages of ripening and wrapping materials (perforated and non perforated white and black polythene bag), while in case of storage temperature, there was gradual increase of physiological weight loss, sugar content (reducing, nonreducing and total sugar) and TSS content. Marketability decreased markedly with the advancement of storage period. All stages of ripening and all wrapping materials were able to keep fruits in marketable condition for 36 days of storage period. But fruits were in better marketable condition when harvested at stage 3 (ripe, yellowish green in colour and crispy pulp) or wrapped with black nonperforated polythene. $5^{\circ} \mathrm{C}$ storage temperature, was able to retain more percentage of fruits in marketable condition with longer storage duration. In case of treatment combinations, fruits harvested at stage 3 , stored at $5^{\circ} \mathrm{C}$ temperature with black non-perforated polythene had the highest physiological weight loss, sugar content (reducing, non-reducing and total sugar) and TSS content while stage 1 fruits stored at $20^{\circ} \mathrm{C}$ with no wrapping (control) had the lowest.
\end{abstract}

Key words : Guava cv. Kazi, Stages of ripening, Storage temperature, Wrapping materials, Quality

\section{INTRODUCTION}

Guava (Psidium guajava L.), an important member of the family Myrtaceae, is widely grown all over the tropics and sub-tropics. The apple of tropics, guava, is a very common fruit in Bangladesh. It is a rich and cheap source of Vit. C (56 mg/100g) (Phandis, 1970), Vit. A and good source of calcium and phosphorus. It contains much iron also, $80 \%$ of which remains in seed (Millar and Bazore, 1945). It also contains $88.5 \%$ water, $2.45 \%$ acid, $4.45 \%$ reducing sugar, $5.23 \%$ non-reducing sugar, $9.75 \%$ total soluble solids and $0.48 \%$ ash

\footnotetext{
${ }^{1}$ Assistant Professor, Department of Agroforestry \& Environmental Science, SAU, Dhaka, Bangladesh

${ }^{2}$ Assistant Professor, Department of Crop Botany, Bangladesh Agricultural University, Mymensingh-2202, Bangladesh

${ }^{3}$ Department of Biotechnology, Bangladesh Agricultural University, Mymensingh-2202, Bangladesh
} 
(Phandis, 1970). Excellent processed materials like jam, jelly, cheese, ketchup, puree, juice, nectar etc. are prepared commercially from ripe guava. Guava juice is an important drink in other countries.

The per capita availability of fruits is far below the recommended level $(85 \mathrm{~g})$ and is further reduced due to high level of post-harvest losses (approximately 30-50\%) in Bangladesh during post-harvest handling, storage and ripening. Reduction of postharvest losses by prolonging the shelf life of guava can help to improve the situation. After harvest a number of factors influence the shelf life and quality of guava fruit. Among them- cultivar, fruiting season, maturity stage, kinds of materials used for wrapping purpose during storage, temperature and humidity prevailing over the storage environment are very much important. During storage period, deterioration of guava are attributed to adverse physico-chemical changes, namely loss of weight due to respiration and transpiration, softening of flesh, loss due to microbial attack and change in sugar and acid content.

Controlled temperature of the storage environment and use of different wrapping materials such as white and black perforated and non-perforated polythene bags, leaves, straw, white and black papers, sawdust, wax etc. are very common practices in the advanced countries (Combrink et al., 1990). No reliable statistical data are available especially in the context of Bangladesh to indicate proper temperature for ideal storage of guava. Moreover, the use of proper wrapping materials is limited at the farmer's level in Bangladesh. The farmers are not interested to increase the production of guava as they can not store them for a longer period after harvest. Information on ripening stage, temperature and wrapping material influencing the shelf life and quality characteristics of any guava cultivar are important for harvesting time, transport, storage and marketing to meet the demand of the fruit for table use on industrial purposes. Dutta et al. (1991) found prolonged shelf life of guava with ethylene absorbent in sealed polythene bag. No systematic and fruitful works have so far been reported in Bangladesh on storage temperature, stage of ripening and wrapping materials on the shelf life of guava. Prolonged shelf life could facilitate the export of guava and earn foreign currency. Keeping all these facts in mind, the present study has been considered to identify the proper stage of ripening of guava, low cost and proper wrapping materials as well as ideal storage temperature to prolong the shelf life and quality so as to encourage the farmer to grow more guavas to minimize the shortage of fruit (guava) in the country.

\section{MATERIALS AND METHODS}

The experiment was conducted at the Germplasm Centre of Fruit Tree Improvement Project (FTIP) of the Department of Horticulture and Laboratories of Horticulture and Biochemistry Departments, Bangladesh Agricultural University, Mymensingh. The cultivar was introduced from Thailand and named as Kazipiara. A total of 1215 unblemished, physically similar fruits of approximately more or less uniform in size, shape and colour were collected. 
The treatments include stages of fruit ripening as defined by Nag (1998) namely : Stage 1 $\left(\mathrm{S}_{1}\right)$ : green but fully matured, texture of pulp is hard, stage $2\left(\mathrm{~S}_{2}\right)$ : colour break down from green to greenish white and texture of pulp is medium hard and stage $3\left(S_{3}\right)$ : ripe, yellowish green in colour and crispy pulp; three incubation temperatures $\left(20,10\right.$ and $5^{\circ} \mathrm{C}$ $=\mathrm{T}_{1}, \mathrm{~T}_{2}$ and $\mathrm{T}_{3}$, respectively) ; four wrapping materials: perforated white polythene bag $\left(\mathrm{W}_{1}\right)$, non-perforated white polythene bag $\left(\mathrm{W}_{2}\right)$, perforated black polythene bag $\left(\mathrm{W}_{3}\right)$, non-perforated black polythene bag $\left(\mathrm{W}_{4}\right)$ and unwrapped fruits as control $\left(\mathrm{W}_{0}\right)$.

During the entire storage period of thirty six days, fruits used for the experiment were keenly observed at 4 days intervals starting from the 4 th day of storage. Weight loss was determined by an OHAUS Triple Beam Balance. Percentage of marketable fruits was determined by eye estimation and finger-feeling method, thus shelf life of fruits was determined. Fifty gram of fruits was used to calculate per cent reducing, non-reducing and total sugar content using the following formulae :

1. $\%$ reducing sugar $=\frac{I \times D \times 100}{T \times W \times 1000}$

(Where, $\mathrm{I}=\mathrm{mg}$ of invert sugar required to reduced to known volume of Fehling's solution, $\mathrm{D}=$ Dilution, $\mathrm{T}=$ Titre and $\mathrm{W}=\mathrm{wt}$. of the sample)

2. $\%$ Non-reducing sugar $=(\%$ Total invert sugars $-\%$ reducing sugars originally present) $\times 0.95$ (conversion factor).

3. $\%$ Total sugars $=\%$ reducing sugar $+\%$ non-reducing sugar

Per cent total soluble solid was obtained from direct reading by placing a drop of juice on the surface of the prism of the refractometer. Experiment was carried out in Randomized Complete Block Design (RCBD) with three replications. Analysis of variance of different parameters was performed by ' $F$ ' variance test. The mean differences were performed by Least Significant Difference test (Gomez and Gomez, 1984).

\section{RESULTS AND DISCUSSION}

\section{Physiological characteristics}

\section{Effect of the treatments on weight loss}

Maximum weight loss $(7.55 \%)$ was recorded at 28 days while minimum $(0.62 \%)$ was at 4 days when the fruits were subjected to a maximum storage period of 36 days. Fruits harvested at stage $1\left(S_{1}\right)$ showed significantly lowest loss of weight with the advancement of shelf life as compared to the fruits harvested at other stages of ripening. As a whole latest harvested $\left(S_{3}\right)$ fruits lost maximum weight and earliest harvested fruits $\left(S_{1}\right)$ lost minimum weight (Table 1). Martinez et al. (1997) reported that greenish yellow fruits significantly reduced weight loss due to the inhibition of transpiration. The highest temperature $\left(20^{\circ} \mathrm{C}\right)$ showed maximum $(9.83 \%)$ weight loss at 16 days duration of storage life after which the fruits got rotten and became unsuitable for human consumption (Table 1). Reduction in weight loss as well as keeping the fruits in an edible condition for a comparatively longer shelf life was achieved by reducing the storage temperature. At 
the end of the total storage period of 36 days, the lowest temperature $\left(5^{\circ} \mathrm{C}\right)$, though caused the highest loss of fruit weight $(12.12 \%)$ than any other treatment, made it possible to keep the fruits in an edible condition up to 36 days of shelf life (Table 1). Weight loss of fruits was increased with the prolongation of shelf life as it was observed at $5^{\circ} \mathrm{C}$.

Table 1. Main effect of stages of ripening, storage temperature and wrapping materials on weight loss (\%) of guava

\begin{tabular}{|c|c|c|c|c|c|c|c|c|c|}
\hline \multirow[t]{2}{*}{ Treatments } & \multicolumn{9}{|c|}{ Weight loss (\%) } \\
\hline & 4 days & 8 days & 12 days & 16 days & 20 days & 24 days & 28 days & 32 days & 36 days \\
\hline \multicolumn{10}{|l|}{ Stages of ripening } \\
\hline Stage $1\left(S_{1}\right)$ & 0.62 & 2.43 & 4.65 & 5.81 & 3.96 & 4.7 & 5.79 & 3.33 & 3.32 \\
\hline Stage $2\left(\mathrm{~S}_{2}\right)$ & 0.81 & 3.07 & 4.96 & 6.22 & 4.83 & 6.27 & 7.49 & 4.27 & 4.39 \\
\hline Stage $3\left(\mathrm{~S}_{3}\right)$ & 0.87 & 3.15 & 5.01 & 6.31 & 4.86 & 6.4 & 7.55 & 4.33 & 4.41 \\
\hline $\operatorname{LSD}_{(0.05)}$ & - & 0.793 & 0.793 & 0.152 & 0.047 & 0.097 & 0.073 & 0.095 & 0.072 \\
\hline Level of significance & NS & * & $* *$ & $* *$ & $* *$ & $* *$ & ** & $* *$ & $* *$ \\
\hline \multicolumn{10}{|l|}{ Storage temperature } \\
\hline $20^{\circ} \mathrm{C}\left(\mathrm{T}_{1}\right)$ & 1.04 & 5.75 & 9.32 & 9.83 & -- & -- & -- & -- & -- \\
\hline $10^{\circ} \mathrm{C}\left(\mathrm{T}_{2}\right)$ & 0.83 & 1.54 & 2.48 & 4.42 & 6.57 & 8.2 & 9.75 & -- & -- \\
\hline $5^{\circ} \mathrm{C}\left(\mathrm{T}_{3}\right)$ & 0.42 & 1.36 & 2.82 & 4.09 & 7.08 & 9.17 & 11.08 & 11.93 & 12.12 \\
\hline $\operatorname{LSD}_{(0.05)}$ & 0.593 & 0.793 & 0.0005 & 0.152 & 0.047 & 0.097 & 0.0005 & 0.095 & 0.0005 \\
\hline Level of significance & * & $* *$ & $* *$ & ** & ** & $* *$ & $* *$ & $* *$ & $* *$ \\
\hline \multicolumn{10}{|l|}{ Wrapping materials } \\
\hline Control $\left(\mathrm{W}_{0}\right)$ & 1.99 & 5.03 & 7.71 & 9.4 & 6.62 & 8.29 & 10.27 & 5.77 & 5.83 \\
\hline $\mathrm{WPP}\left(\mathrm{W}_{1}\right)$ & 0.8 & 3 & 5.57 & 7.05 & 5.38 & 7.04 & 7.98 & 4.51 & 4.5 \\
\hline $\mathrm{WNP}\left(\mathrm{W}_{2}\right)$ & 0.12 & 1.73 & 2.83 & 3.7 & 2.62 & 3.33 & 4.29 & 2.59 & 2.71 \\
\hline $\mathrm{BPP}\left(\mathrm{W}_{3}\right)$ & 0.8 & 2.97 & 5.47 & 6.96 & 5.34 & 7.01 & 7.92 & 4.43 & 4.44 \\
\hline $\mathrm{BNP}\left(\mathrm{W}_{4}\right)$ & 0.12 & 1.69 & 2.79 & 3.44 & 2.6 & 3.28 & 4.25 & 2.59 & 2.71 \\
\hline $\operatorname{LSD}_{(0.05)}$ & 0.023 & 0.023 & 0.0007 & 0.197 & 0.061 & 0.125 & 0.0007 & 0.123 & 0.0007 \\
\hline Level of significance & ** & ** & ** & $* *$ & $* *$ & $* *$ & $* *$ & $* *$ & ** \\
\hline
\end{tabular}

** = Significant at 0.01 level

Stage $1\left(\mathrm{~S}_{1}\right)=$ Green but fully matured fruit with hard pulp $\mathrm{W}_{0}=$ Control, $\mathrm{W}_{1}=$ Perforated white polythene bag

Stage $2\left(\mathrm{~S}_{2}\right)=$ Greenish white fruit with medium hard pulp W2 = Non-perforated white polythene bag

Stage $3\left(\mathrm{~S}_{3}\right)=$ Ripe yellowish green fruit with crispy pulp $W_{3}=$ Perforated black polythene bag

W4 $=$ Non-perforated black polythene bag

Use of wrapping materials reduced weight loss in all cases as compared to the control. During the total storage period, weight loss was increased up to 28 days in all cases then decreased. At 28 days of shelf life fruits preserved with black non-perforated polythene $\left(\mathrm{W}_{4}\right)$ lost minimum weight $(4.25 \%)$ followed by white non-perforated polythene $\left(\mathrm{W}_{3}\right)$ (Table 1). Maximum (18.30\%) weight loss was found for the treatment combination of $\mathrm{S}_{3} \mathrm{~T}_{3} \mathrm{~W}_{0}$ at 36 days of shelf life (Data not shown) followed by $\mathrm{S}_{3} \mathrm{~T}_{1} \mathrm{~W}_{0}$ combination at 16 
days of shelf life. The lowest weight loss was least in fruits harvested at stage 1, kept at $5^{\circ} \mathrm{C}$ of storage temperature and in non-perforated polythene bag. Oosthuyse (1997) expressed similar opinion regarding weight loss and shrivels and increased shelf life of guava. The reduction of weight loss could be due to the presence of physical barrier in gas diffusion through fruit stomata. The exchange of gas takes place between internal tissues and external atmosphere. It is manifested that the vapour pressure gradient may occur between fruit tissue and external atmosphere causing least loss of weight. In case of fruits harvested at stage 1 and stored at $5^{\circ} \mathrm{C}$ had lower rate of evaporation, transpiration or respiration which had an effect on lower loss of weight in fruits. On the contrary, high percentage of total weight loss occurred in control (no wrapping materials) fruits could be higher rate of transpiration, respiration or evaporation. Minimum total weight losses in polythene bag, storage temperature and stages of ripening are supported by the findings of Martinez et al. (1997).

\section{Effect of the treatments on per cent marketable fruits}

Fruits harvested at all three stages remained in the highest marketable condition (100\%) at 4 days after storage. The highest reduction of per cent marketable fruits was noticed at 36 days in stage $3\left(\mathrm{~S}_{3}\right)$ fruits $(12.69 \%)$ and stage $1\left(\mathrm{~S}_{1}\right)$ fruits were in lowest $(7.92 \%)$ marketable condition (Table 2). At 36 days after storage, only the fruits stored at $5^{\circ} \mathrm{C}\left(\mathrm{T}_{3}\right)$ were in marketable condition $(28.70 \%)$ whereas in case of fruits stored at $10^{\circ} \mathrm{C}$ and $20^{\circ} \mathrm{C}$ $100 \%$ fruits were rotten at 32 days and 20 days of storage, respectively (Table 2).

At the end of 36 days storage duration, $11.58 \%$ fruits were in marketable condition in case of black non-perforated polythene $\left(\mathrm{W}_{4}\right)$ which was statistically higher than any other treatments. Whereas, the control treatment $\left(\mathrm{W}_{0}\right)$ was able to preserve only $8.28 \%$ fruits in marketable condition (Table 2). All the treatments combinedly acted upon the percentage of marketable fruits during storage in which the treatment combination of $\mathrm{S}_{3} \mathrm{~T}_{3} \mathrm{~W}_{4}$ was statistically different from any other combination as it preserved the highest percentage of fruits $(47.17 \%)$ in marketable condition at 36 days of storage (Data not shown). In case of per cent marketable fruits, guava showed significant decrease with the advancement of storage duration due to all storage treatments and their combinations. Such results of the present study were partially supported by Combrink et al. (1990). They reported that storage in NPB and IPB significantly increased the marketable fruit from $21.7 \%$ to $61.7 \%$ and $68.3 \%$, respectively at $4.5 \%$ for 3 weeks. Storage temperature and ripening of fruit had a significant effect on decay.

\section{Chemical characteristics}

\section{Effect of the treatments on per cent reducing sugar}

Maximum reducing sugar content $(3.61 \%)$ was found in stage $3\left(S_{3}\right)$ fruits at 16 days whereas, minimum reducing sugar content $(0.95 \%)$ was recorded in stage $1\left(\mathrm{~S}_{1}\right)$ fruits at 36 days after storage. In all cases reducing sugar content was increased up to 16 days of storage then it decreased (Table 3). Highest reducing sugar content (3.64\%) was observed in fruits stored at $5^{\circ} \mathrm{C}\left(\mathrm{T}_{3}\right)$ after 32 days of storage (Table 3 ). Wrapping materials exerted a significant influence on reducing sugar content of guava. Reducing sugar content was 
highest $(3.32 \%)$ in fruits wrapped with black non-perforated polythene $\left(\mathrm{W}_{4}\right)$ and lowest $(1.09 \%)$ when fruits were unwrapped $\left(\mathrm{W}_{0}\right)$. In all cases, reducing sugar content increased up to 16 days of shelf life and decreased thereafter (Table 3).

Table 2. Main effect of stages of ripening, storage temperature and wrapping materials on per cent marketable fruits of guava

\begin{tabular}{|c|c|c|c|c|c|c|c|c|c|}
\hline \multirow[t]{2}{*}{ Treatments } & \multicolumn{9}{|c|}{ Marketable fruits (\%) } \\
\hline & 4 days & 8 days & 12 days & 16 days & 20 days & 24 days & 28 days & 32 days & 36 days \\
\hline \multicolumn{10}{|l|}{ Stages of ripening } \\
\hline Stage $1\left(\mathrm{~S}_{1}\right)$ & 100 & 96.09 & 75.08 & 61.57 & 48.23 & 37.56 & 22.71 & 13.77 & 7.92 \\
\hline Stage $2\left(\mathrm{~S}_{2}\right)$ & 100 & 98.53 & 81.2 & 68.97 & 55.06 & 49.89 & 29.71 & 15.71 & 9.83 \\
\hline Stage $3\left(S_{3}\right)$ & 100 & 99.8 & 86.78 & 72.89 & 62.42 & 57.8 & 34.97 & 22 & 12.69 \\
\hline $\operatorname{LSD}_{(0.05)}$ & 0.06 & 0.24 & 0.126 & 0.102 & 0.23 & 0.204 & 0.201 & 0.201 & 0.359 \\
\hline Level of significance & NS & ** & ** & ** & ** & ** & ** & ** & ** \\
\hline \multicolumn{10}{|l|}{ Storage temperature } \\
\hline $20^{\circ} \mathrm{C}\left(\mathrm{T}_{1}\right)$ & 99.99 & 96.93 & 49.32 & 19.23 & -- & -- & -- & -- & -- \\
\hline $10^{\circ} \mathrm{C}\left(\mathrm{T}_{2}\right)$ & 100 & 98.43 & 96.2 & 89.76 & 78.83 & 68.24 & 19.46 & -- & -- \\
\hline $5^{\circ} \mathrm{C}\left(\mathrm{T}_{3}\right)$ & 100 & 99.06 & 97.54 & 94.43 & 86.88 & 77.01 & 67.93 & 51.48 & 28.7 \\
\hline $\operatorname{LSD}_{(0.05)}$ & 0.06 & 0.24 & 0.126 & 0.102 & 0.23 & 0.204 & 0.201 & -- & -- \\
\hline Level of significance & NS & ** & ** & ** & ** & ** & ** & ** & ** \\
\hline \multicolumn{10}{|l|}{ Wrapping materials } \\
\hline Control $\left(\mathrm{W}_{0}\right)$ & 99.95 & 96.04 & 74.76 & 59.87 & 48.26 & 40.77 & 22.36 & 10.78 & 8.28 \\
\hline $\mathrm{WPP}\left(\mathrm{W}_{1}\right)$ & 100 & 98.26 & 79.61 & 67.52 & 54 & 47.16 & 28.17 & 15.67 & 9 \\
\hline $\mathrm{WNP}\left(\mathrm{W}_{2}\right)$ & 100 & 98.94 & 85.34 & 71.61 & 59.56 & 52.94 & 32.82 & 21.33 & 11.46 \\
\hline $\mathrm{BPP}\left(\mathrm{W}_{3}\right)$ & 100 & 98.37 & 79.74 & 68.14 & 54.5 & 47.98 & 28.77 & 16.13 & 10.43 \\
\hline $\mathrm{BNP}\left(\mathrm{W}_{4}\right)$ & 100 & 99.09 & 85.67 & 71.93 & 59.87 & 53.23 & 33.53 & 21.89 & 11.58 \\
\hline $\operatorname{LSD}_{(0.05)}$ & 0.077 & 0.272 & 0.162 & 0.132 & 0.297 & 0.263 & 0.259 & 0.259 & 0.433 \\
\hline Level of significance & NS & ** & ** & ** & ** & $* *$ & ** & ** & ** \\
\hline $\begin{array}{l}* *=\text { Significant at } 0.01 \text { lev } \\
\text { Stage } 1\left(\mathrm{~S}_{1}\right)=\text { Green but } \mathrm{f} \\
\text { Stage } 2\left(\mathrm{~S}_{2}\right)=\text { Greenish } \mathrm{w} \\
\text { Stage } 3\left(\mathrm{~S}_{3}\right)=\text { Ripe yellow }\end{array}$ & $\begin{array}{l}\text { he fruit } \\
\text { t greer }\end{array}$ & $\begin{array}{l}\text { th medi } \\
\text { uit with }\end{array}$ & $\begin{array}{l}\text { ium hard } \mathrm{p} \\
\text { crispy pul }\end{array}$ & $\begin{array}{ll}\text { pulp } & \mathrm{W}_{0}= \\
\text { oulp } & \mathrm{W} 2= \\
\text { lp } & \mathrm{W}_{3}= \\
& \mathrm{W} 4=\end{array}$ & $\begin{array}{l}=\text { Control } \\
=\text { Non-per } \\
=\text { Perforate } \\
=\text { Non-per }\end{array}$ & $\begin{array}{l}\mathrm{W}_{1}=\text { Perf } \\
\text { rforated } \mathrm{w} \\
\text { ed black } \mathrm{p} \\
\text { rforated } \mathrm{bl}\end{array}$ & $\begin{array}{l}\text { forated wh } \\
\text { hite polyt } \\
\text { olythene } k \\
\text { lack polytl }\end{array}$ & $\begin{array}{l}\text { hite polyth } \\
\text { thene bag } \\
\text { bag } \\
\text { hene bag }\end{array}$ & ne bag \\
\hline
\end{tabular}

The combined effect of stages of ripening, storage temperature and wrapping materials significantly influenced the percentage of reducing sugar at different days after storage. Reducing sugar content was maximum $(4.50 \%)$ in case of treatment combination of $\mathrm{S}_{3} \mathrm{~T}_{3} \mathrm{~W}_{4}$ at 32 days of storage life which was significantly higher than any other treatment combinations (Data not shown). An increase in reducing sugar content during storage was probably due to enzymatic conversion of starch to reducing sugar. Reducing sugar content was maximum in case of fruits harvested at stage 3 , stored at $5^{\circ} \mathrm{C}$ and using black 
non-perforated polythene during the total shelf life. The present study is in agreement with the results of Augustin et al. (1988). They stated that storing guava at $26^{\circ} \mathrm{C}, 20^{\circ} \mathrm{C}$ and $5^{\circ} \mathrm{C}$ showed significant increases in reducing sugar at all temperature using various kinds of wrapping materials and fruits harvested at different stages.

Table 3. Main effect of stages of ripening, storage temperature and wrapping materials on per cent reducing sugar of guava

\begin{tabular}{|c|c|c|c|c|c|c|c|c|c|}
\hline \multirow[t]{2}{*}{ Treatments } & \multicolumn{9}{|c|}{ Reducing sugar (\%) } \\
\hline & 4 days & 8 days & 12 days & 16 days & 20 days & 24 days & 28 days & 32 days & 36 days \\
\hline \multicolumn{10}{|l|}{ Stages of ripening } \\
\hline Stage $1\left(S_{1}\right)$ & 2.16 & 2.33 & 2.42 & 2.5 & 1.74 & 1.82 & 1.87 & 0.95 & 0.95 \\
\hline Stage $2\left(\mathrm{~S}_{2}\right)$ & 2.89 & 3.16 & 3.25 & 3.35 & 2.33 & 2.4 & 2.46 & 1.22 & 1.21 \\
\hline Stage $3\left(S_{3}\right)$ & 3.08 & 3.28 & 3.32 & 3.61 & 2.63 & 2.71 & 2.78 & 1.47 & 1.46 \\
\hline $\operatorname{LSD}_{(0.05)}$ & 0.0005 & 0.047 & 0.047 & 0.149 & 0.0005 & 0.0005 & 0.0005 & 0.0005 & 0.0005 \\
\hline Level of significance & ** & $* *$ & ** & $* *$ & $* *$ & ** & ** & ** & ** \\
\hline \multicolumn{10}{|l|}{ Storage temperature } \\
\hline $20^{\circ} \mathrm{C}\left(\mathrm{T}_{1}\right)$ & 2.63 & 2.88 & 2.9 & 2.87 & -- & -- & -- & -- & -- \\
\hline $10^{\circ} \mathrm{C}\left(\mathrm{T}_{2}\right)$ & 2.73 & 2.85 & 2.97 & 3.2 & 3.32 & 3.44 & 3.49 & -- & -- \\
\hline $5^{\circ} \mathrm{C}\left(\mathrm{T}_{3}\right)$ & 2.76 & 3.04 & 3.12 & 3.39 & 3.38 & 3.5 & 3.62 & 3.64 & 3.61 \\
\hline $\mathrm{LSD}_{(0.05)}$ & 0.0005 & 0.047 & 0.047 & 0.149 & 0.0005 & 0.0005 & 0.0005 & 0.0005 & 0.0005 \\
\hline Level of significance & $* *$ & $* *$ & $* *$ & $* *$ & $* *$ & $* *$ & $* *$ & $* *$ & $* *$ \\
\hline \multicolumn{10}{|l|}{ Wrapping materials } \\
\hline Control $\left(\mathrm{W}_{0}\right)$ & 2.64 & 2.75 & 2.8 & 2.96 & 2.04 & 2.06 & 2.13 & 1.1 & 1.09 \\
\hline $\mathrm{WPP}\left(\mathrm{W}_{1}\right)$ & 2.7 & 2.9 & 2.95 & 3.13 & 2.26 & 2.34 & 2.39 & 1.22 & 1.21 \\
\hline $\mathrm{WNP}\left(\mathrm{W}_{2}\right)$ & 2.75 & 3.01 & 3.1 & 3.2 & 2.3 & 2.4 & 2.46 & 1.25 & 1.25 \\
\hline $\mathrm{BPP}\left(\mathrm{W}_{3}\right)$ & 2.7 & 2.96 & 3.01 & 3.15 & 2.27 & 2.35 & 2.4 & 1.22 & 1.22 \\
\hline $\mathrm{BNP}\left(\mathrm{W}_{4}\right)$ & 2.75 & 3.01 & 3.11 & 3.32 & 2.31 & 2.4 & 2.46 & 1.26 & 1.25 \\
\hline $\operatorname{LSD}_{(0.05)}$ & 0.0007 & 0.061 & 0.061 & 0.193 & 0.0007 & 0.0007 & 0.0007 & 0.0007 & 0.0007 \\
\hline Level of significance & ** & ** & ** & $* *$ & $* *$ & $* *$ & $* *$ & ** & $* *$ \\
\hline $\begin{array}{l}* *=\text { Significant at } 0.01 \text { lev } \\
\text { Stage } 1\left(\mathrm{~S}_{1}\right)=\text { Green but } \mathrm{f} \\
\text { Stage } 2\left(\mathrm{~S}_{2}\right)=\text { Greenish } \mathrm{w} \\
\text { Stage } 3\left(\mathrm{~S}_{3}\right)=\text { Ripe yellow }\end{array}$ & $\begin{array}{l}\text { ally matur } \\
\text { hite fruit } \\
\text { ish green }\end{array}$ & $\begin{array}{l}\text { with medi } \\
\text { fruit with }\end{array}$ & $\begin{array}{l}\text { with hard } p \\
\text { ium hard } p \\
\text { crispy pul }\end{array}$ & $\begin{array}{ll}\text { pulp } & \mathrm{W}_{0}= \\
\text { oulp } & \mathrm{W} 2= \\
\text { lp } & \mathrm{W}_{3}= \\
& \mathrm{W} 4=\end{array}$ & $\begin{array}{l}=\text { Control, } \\
=\text { Non-per } \\
=\text { Perforate } \\
=\text { Non-per }\end{array}$ & $\begin{array}{l}W_{1}=\text { Perf } \\
\text { forated } w \\
\text { d black } \mathrm{pc} \\
\text { forated bl }\end{array}$ & $\begin{array}{l}\text { orated wh } \\
\text { hite polyt } \\
\text { olythene b } \\
\text { lack polytl }\end{array}$ & $\begin{array}{l}\text { hite polyth } \\
\text { thene bag } \\
\text { bag } \\
\text { hene bag }\end{array}$ & ne bag \\
\hline
\end{tabular}

\section{Effect of the treatments on per cent non-reducing sugar content}

At 16 days of shelf life fruits harvested at stage $1\left(\mathrm{~S}_{1}\right)$ had the lowest percentage $(4.30 \%)$ of non-reducing sugar while fruits harvested at stage $3\left(S_{3}\right)$ had the highest percentage of non-reducing sugar $(5.21 \%)$. Afterwards the percentage of non-reducing sugar started to decrease significantly and reached to a minimum of $1.34 \%$ in $S_{1}$ fruits (Table 4). At 16 days after storage, non-reducing sugar content was highest (4.95\%) in case of fruits 
preserved at $5^{\circ} \mathrm{C}$ which was followed by fruits preserved at $10^{\circ} \mathrm{C}(4.75 \%)$ and $20^{\circ} \mathrm{C}$ $(4.47 \%)$, respectively. Further increase in non-reducing sugar content was observed in case of fruits preserved at $10^{\circ} \mathrm{C}$ and $5^{\circ} \mathrm{C}$. Guava fruits preserved at $5^{\circ} \mathrm{C}$ reached a maximum non-reducing sugar content of $5.52 \%$ at 32 days after storage (Table 4 ). At 16 days of storage, non-reducing sugar content was maximum $(4.94 \%)$ in fruits wrapped with black non-perforated polythene $\left(\mathrm{W}_{4}\right)$ whereas minimum $(4.35 \%)$ was recorded in case of control $\left(\mathrm{W}_{0}\right)$ (Table 4). Non-reducing sugar content was increased with the advancement of storage duration up to 16 days thereafter decreased. Stages of ripening, post-harvest storage temperature and use of different kinds of wrapping materials combinedly produced significant effect on non-reducing sugar content. Percentage of non-reducing sugar was maximum $(6.49 \%)$ in case of the treatment combination of $\mathrm{S}_{3} \mathrm{~T}_{3} \mathrm{~W}_{4}$ which was significantly higher than any other treatment combinations (Data not shown). Non-reducing sugar content of guava increased rapidly for a certain period of storage duration at different stages of ripening. The rapid increase in all stages may be due to the breakdown of starch into non-reducing sugar and finally this non-reducing sugar was converted into reducing sugar resulting a slow increase in non-reducing sugar of guava, which is also similar with the results stated by Ramchandra and Chandra (1995). They observed that sugar content of guava was increased for a certain period of shelf life and declined thereafter during the storage period when stored at different temperature, using wrapping materials.

\section{Effect of the treatments on per cent total sugar}

Percentage of total sugar was increased up to 16 days of storage in all cases and then decreased. At 16 days of shelf life the highest total sugar content $(8.73 \%)$ was recorded in stage $3\left(S_{3}\right)$ fruits and the lowest $(6.80 \%)$ was recorded in stage $1\left(S_{1}\right)$ fruits. However, at the end of storage i.e. at 36 days, maximum total sugar content $(3.55 \%)$ was recorded in stage $3\left(\mathrm{~S}_{3}\right)$ guavas while minimum $(2.54 \%)$ was in stage $1\left(\mathrm{~S}_{1}\right)$ guavas (Table 5). Total sugar content gradually increased in case of all three temperature treatments before the fruits were subjected to deterioration. Accordingly, total sugar content was highest $(9.13 \%)$ in case of fruits stored at $5^{\circ} \mathrm{C}$ temperature at 36 days which was followed by fruits stored at $10^{\circ} \mathrm{C}$ and $20^{\circ} \mathrm{C}$, respectively (Table 5). Total sugar content was increased and reached to a maximum value of $8.15 \%$ in case of fruits wrapped with black nonperforated polythene $\left(\mathrm{W}_{4}\right)$ which was significantly higher than any other treatments. Minimum total sugar $(2.73 \%)$ content was recorded at the end of storage period in case of fruits without any wrapping materials i.e. control ( $\left.\mathrm{W}_{0}\right)$ (Table 5).

Total sugar content increased with the advancement of shelf life then decreased before deterioration of fruits. Maximum total sugar content $(10.99 \%)$ was found in case of the treatment combination of $\mathrm{S}_{3} \mathrm{~T}_{3} \mathrm{~W}_{4}$ which was significantly higher than any other treatment combinations (Data not shown). 
Table 4. Main effect of stages of ripening, storage temperature and wrapping materials on per cent non-reducing sugar of guava

\begin{tabular}{|c|c|c|c|c|c|c|c|c|c|}
\hline \multirow[t]{2}{*}{ Treatments } & \multicolumn{9}{|c|}{ Non-reducing sugar (\%) } \\
\hline & 4 days & 8 days & 12 days & 16 days & 20 days & 24 days & 28 days & 32 days & 36 days \\
\hline \multicolumn{10}{|l|}{ Stages of ripening } \\
\hline Stage $1\left(S_{1}\right)$ & 4.1 & 4.25 & 4.28 & 4.3 & 3.02 & 3.07 & 3.14 & 1.34 & 1.6 \\
\hline Stage $2\left(\mathrm{~S}_{2}\right)$ & 4.24 & 4.51 & 4.69 & 4.76 & 3.31 & 3.34 & 3.44 & 1.78 & 1.74 \\
\hline Stage $3\left(\mathrm{~S}_{3}\right)$ & 4.58 & 4.78 & 5.15 & 5.21 & 3.77 & 3.89 & 3.97 & 2.1 & 2.09 \\
\hline $\operatorname{LSD}_{(0.05)}$ & 0.0005 & 0.047 & 0.079 & 0.0005 & 0.047 & 0.05 & 0.0005 & 0.05 & 0.047 \\
\hline Level of significance & ** & $* *$ & $* *$ & $* *$ & $* *$ & $* *$ & $* *$ & ** & $* *$ \\
\hline \multicolumn{10}{|l|}{ Storage temperature } \\
\hline $20^{\circ} \mathrm{C}\left(\mathrm{T}_{1}\right)$ & 4.29 & 4.49 & 4.54 & 4.47 & -- & -- & -- & -- & -- \\
\hline $10^{\circ} \mathrm{C}\left(\mathrm{T}_{2}\right)$ & 4.26 & 4.43 & 4.65 & 4.75 & 4.85 & 4.97 & 5.07 & -- & -- \\
\hline $5^{\circ} \mathrm{C}\left(\mathrm{T}_{3}\right)$ & 4.37 & 4.62 & 4.39 & 4.05 & 5.26 & 5.33 & 5.47 & 5.52 & 5.42 \\
\hline $\operatorname{LSD}_{(0.05)}$ & 0.0005 & 0.047 & 0.793 & 0.0005 & 0.047 & 0.05 & 0.0005 & 0.05 & 0.047 \\
\hline Level of significance & ** & $* *$ & $* *$ & $* *$ & $* *$ & $* *$ & $* *$ & $* *$ & ** \\
\hline \multicolumn{10}{|l|}{ Wrapping materials } \\
\hline Control $\left(\mathrm{W}_{0}\right)$ & 4.04 & 4.16 & 4.34 & 4.35 & 3.23 & 3.15 & 3.07 & 1.65 & 1.63 \\
\hline WPP $\left(W_{1}\right)$ & 4.31 & 4.54 & 4.71 & 4.77 & 3.52 & 3.46 & 3.43 & 1.85 & 1.84 \\
\hline $\mathrm{WNP}\left(\mathrm{W}_{2}\right)$ & 4.43 & 4.67 & 4.86 & 4.93 & 3.64 & 3.57 & 3.65 & 1.9 & 1.88 \\
\hline $\mathrm{BPP}\left(\mathrm{W}_{3}\right)$ & 4.32 & 4.51 & 4.74 & 4.79 & 3.53 & 3.42 & 3.41 & 1.89 & 1.84 \\
\hline $\mathrm{BNP}\left(\mathrm{W}_{4}\right)$ & 4.44 & 4.68 & 4.88 & 4.94 & 3.65 & 3.57 & 3.47 & 1.9 & 1.85 \\
\hline $\operatorname{LSD}_{(0.05)}$ & 0.0007 & 0.061 & 0.023 & 0.0007 & 0.0007 & 0.065 & 0.061 & 0.065 & 0.061 \\
\hline Level of significance & ** & ** & ** & ** & ** & ** & ** & ** & ** \\
\hline $\begin{array}{l}* *=\text { Significant at } 0.01 \text { lev } \\
\text { Stage } 1\left(S_{1}\right)=\text { Green but } f \\
\text { Stage } 2\left(S_{2}\right)=\text { Greenish } w \\
\text { Stage } 3\left(S_{3}\right)=\text { Ripe yellow }\end{array}$ & $\begin{array}{l}\text { fruit } \\
\text { h gree }\end{array}$ & $\begin{array}{l}\text { fruit w } \\
\text { th medi } \\
\text { uit with }\end{array}$ & $\begin{array}{l}\text { with hard } \\
\text { ium hard } \\
\text { crispy } \mathrm{p}\end{array}$ & $\begin{array}{ll}\text { pulp } & \mathrm{W}_{0}= \\
\text { oulp } & \mathrm{W}_{2} \\
\text { lp } & \mathrm{W}_{3} \\
& \mathrm{~W} 4\end{array}$ & $\begin{array}{l}=\text { Control }, \\
=\text { Non-per } \\
=\text { Perforate } \\
=\text { Non-per }\end{array}$ & $\begin{array}{l}\text { fforated w } \\
\text { ed black p } \\
\text { rforated bl }\end{array}$ & $\begin{array}{l}\text { forated wh } \\
\text { hite polyt } \\
\text { olythene } b \\
\text { lack polytl }\end{array}$ & $\begin{array}{l}\text { thene bag } \\
\text { bag } \\
\text { hene bag }\end{array}$ & ne ba \\
\hline
\end{tabular}

The gradual increase in total sugar content found in the present study is in agreement with the results of Tsuda et al. (1999). They stated that total sugar content of guava fruits was increased during storage at different stages of ripening and storage temperature also using wrapping materials. The increase in total sugar content may be due to conversion of starch into sugars.

\section{Effect of the treatments on per cent TSS}

Maximum TSS $(9.67 \%)$ was found in case of fruits harvested at stage $3\left(S_{3}\right)$ which was followed by stage $2\left(\mathrm{~S}_{2}\right)$ and stage $1\left(\mathrm{~S}_{1}\right)$ fruits. Minimum TSS $(3.17 \%)$ was found the end of storage in case of stage $1\left(S_{1}\right)$ which was followed by fruits harvested at stage $2\left(S_{2}\right)$ and stage $3\left(S_{3}\right)$, respectively (Table 6 ). As the duration of storage extended, percentage of 
TSS increased, reaching to a maximum value and then declined. The highest TSS (10.68\%) was recorded in case of fruits stored at $5^{\circ} \mathrm{C}$ at 32 days of storage which was followed by fruits stored at $10^{\circ} \mathrm{C}$ and $20^{\circ} \mathrm{C}$, respectively (Table 6). Per cent TSS was increased with the advancement of storage period and reached to a maximum value $(9.15 \%)$ at 16 days of shelf life in case of fruits wrapped with black non-perforated polythene $\left(\mathrm{W}_{4}\right)$ which was followed by the treatment $\mathrm{W}_{2}(9.12 \%)$ (Table 6).

Table 5. Main effect of stages of ripening, storage temperature and wrapping materials on per cent total sugar of guava

\begin{tabular}{|c|c|c|c|c|c|c|c|c|c|}
\hline \multirow[t]{2}{*}{ Treatments } & \multicolumn{9}{|c|}{ Total sugar $(\%)$} \\
\hline & 4 days & 8 days & 12 days & 16 days & 20 days & 24 days & 28 days & 32 days & 36 days \\
\hline \multicolumn{10}{|l|}{ Stages of ripening } \\
\hline Stage $1\left(S_{1}\right)$ & 6.34 & 6.49 & 6.71 & 6.8 & 5.03 & 4.89 & 4.76 & 2.57 & 2.54 \\
\hline Stage $2\left(\mathrm{~S}_{2}\right)$ & 7.13 & 7.67 & 7.93 & 8.11 & 5.9 & 5.77 & 5.64 & 2.99 & 2.97 \\
\hline Stage $3\left(S_{3}\right)$ & 7.64 & 8.07 & 8.49 & 8.73 & 6.74 & 6.6 & 6.41 & 3.57 & 3.55 \\
\hline $\operatorname{LSD}_{(0.05)}$ & 0.052 & 0.052 & 0.059 & 0.052 & 0.035 & 0.0005 & 0.035 & 0.0005 & 0.0005 \\
\hline Level of significance & ** & ** & ** & ** & ** & $* *$ & ** & ** & $* *$ \\
\hline \multicolumn{10}{|l|}{ Storage temperature } \\
\hline $20^{\circ} \mathrm{C}\left(\mathrm{T}_{1}\right)$ & 6.88 & 7.34 & 7.35 & 7.44 & -- & -- & -- & -- & -- \\
\hline $10^{\circ} \mathrm{C}\left(\mathrm{T}_{2}\right)$ & 6.99 & 7.26 & 7.64 & 7.94 & 8.17 & 8.41 & 8.56 & -- & -- \\
\hline $5^{\circ} \mathrm{C}\left(\mathrm{T}_{3}\right)$ & 7.14 & 7.63 & 8.05 & 8.36 & 8.63 & 8.85 & 9.06 & 9.11 & 9.13 \\
\hline $\operatorname{LSD}_{(0.05)}$ & 0.052 & 0.052 & 0.059 & 0.052 & 0.035 & 0.0005 & 0.035 & 0.0005 & 0.0005 \\
\hline Level of significance & ** & ** & ** & ** & ** & ** & ** & ** & ** \\
\hline \multicolumn{10}{|l|}{ Wrapping materials } \\
\hline Control $\left(\mathrm{W}_{0}\right)$ & 6.68 & 6.87 & 7.15 & 7.24 & 5.39 & 5.21 & 5.14 & 2.75 & 2.73 \\
\hline $\mathrm{WPP}\left(\mathrm{W}_{1}\right)$ & 7.01 & 7.37 & 7.7 & 7.91 & 5.92 & 5.8 & 5.65 & 3.08 & 3.05 \\
\hline $\mathrm{WNP}\left(\mathrm{W}_{2}\right)$ & 7.14 & 7.68 & 7.97 & 8.13 & 6.1 & 5.97 & 5.76 & 3.15 & 3.13 \\
\hline $\mathrm{BPP}\left(\mathrm{W}_{3}\right)$ & 6.98 & 7.43 & 7.74 & 7.97 & 5.93 & 5.81 & 5.67 & 3.08 & 3.06 \\
\hline $\mathrm{BNP}\left(\mathrm{W}_{4}\right)$ & 7.19 & 7.7 & 7.99 & 8.15 & 6.11 & 5.98 & 5.78 & 3.16 & 3.13 \\
\hline $\operatorname{LSD}_{(0.05)}$ & 0.067 & 0.067 & 0.017 & 0.067 & 0.046 & 0.0007 & 0.046 & 0.0007 & 0.0007 \\
\hline Level of significance & $* *$ & $* *$ & $* *$ & ** & $* *$ & $* *$ & ** & ** & $* *$ \\
\hline $\begin{array}{l}* *=\text { Significant at } 0.01 \text { le } \\
\text { Stage } 1\left(S_{1}\right)=\text { Green but } \\
\text { Stage } 2\left(S_{2}\right)=\text { Greenish } \\
\text { Stage } 3\left(S_{3}\right)=\text { Ripe yellor }\end{array}$ & te fruit & $\begin{array}{l}\text { vith mec } \\
\text { fruit wit }\end{array}$ & $\begin{array}{l}\text { vith har } \\
\text { um har } \\
\text { crispy }\end{array}$ & $\begin{array}{ll}\text { pulp } & \mathrm{W}_{0}= \\
\text { oulp } & \mathrm{W}_{2}= \\
\text { lp } & \mathrm{W}_{3}= \\
& \mathrm{W} 4=\end{array}$ & $\begin{array}{l}=\text { Control }, \\
=\text { Non-per } \\
=\text { Perforate } \\
=\text { Non-per }\end{array}$ & $\begin{array}{l}\text { rforated } \\
\text { ed black } \\
\text { rforated }\end{array}$ & $\begin{array}{l}\text { te po } \\
\text { yther } \\
\text { k po }\end{array}$ & $\begin{array}{l}\text { ne bag } \\
\text { ne bag }\end{array}$ & he bag \\
\hline
\end{tabular}

Maximum TSS (11.97\%) was found in case of the treatment combination of $\mathrm{S}_{3} \mathrm{~T}_{3} \mathrm{~W}_{4}$ at 32 days of storage which was followed by the treatment combination of $\mathrm{S}_{3} \mathrm{~T}_{3} \mathrm{~W}_{2}(11.95 \%)$ while minimum increase of TSS (6.99\%) was found in case of the treatment combination of $\mathrm{S}_{1} \mathrm{~T}_{1} \mathrm{~W}_{0}$ at 12 days after storage (Data not shown). The increase in per cent TSS contents 
found in the present investigation is in partial agreement with the research findings of Medlicott et al. (1990). An increase in TSS content up to a certain period during storage was possibly due to hydrolysis of starch into sugar.

Table 6. Main effect of stages of ripening, storage temperature and wrapping materials on per cent TSS change of guava

\begin{tabular}{|c|c|c|c|c|c|c|c|c|c|}
\hline \multirow[t]{2}{*}{ Treatments } & \multicolumn{9}{|c|}{ Total sugar (\%) } \\
\hline & 4 days & 8 days & 12 days & 16 days & 20 days & 24 days & 28 days & 32 days & 36 days \\
\hline \multicolumn{10}{|l|}{ Stages of ripening } \\
\hline Stage $1\left(S_{1}\right)$ & 6.92 & 7.42 & 7.73 & 7.98 & 6.07 & 5.91 & 5.77 & 3.23 & 3.17 \\
\hline Stage $2\left(\mathrm{~S}_{2}\right)$ & 7.64 & 8.43 & 8.72 & 8.99 & 6.66 & 6.51 & 6.33 & 3.54 & 3.5 \\
\hline Stage $3\left(S_{3}\right)$ & 8.23 & 8.99 & 9.35 & 9.67 & 7.62 & 7.41 & 7.14 & 3.92 & 3.89 \\
\hline $\operatorname{LSD}_{(0.05)}$ & 0.031 & 0.0005 & 0.069 & 0.0005 & 0.047 & 0.047 & 0.0005 & 0.0005 & 0.0005 \\
\hline Level of significance & ** & ** & ** & ** & ** & ** & ** & ** & ** \\
\hline \multicolumn{10}{|l|}{ Storage temperature } \\
\hline $20^{\circ} \mathrm{C}\left(\mathrm{T}_{1}\right)$ & 7.52 & 8.03 & 8.23 & 8.02 & -- & -- & -- & -- & -- \\
\hline $10^{\circ} \mathrm{C}\left(\mathrm{T}_{2}\right)$ & 7.53 & 8.4 & 8.78 & 9.04 & 9.27 & 9.78 & 9.56 & -- & -- \\
\hline $5^{\circ} \mathrm{C}\left(\mathrm{T}_{3}\right)$ & 7.75 & 8.4 & 8.79 & 9.58 & 9.97 & 10.28 & 10.57 & 10.68 & 10.55 \\
\hline $\operatorname{LSD}_{(0.05)}$ & 0.031 & 0.0005 & 0.069 & 0.0005 & 0.0005 & 0.047 & 0.047 & 0.0005 & 0.0005 \\
\hline Level of significance & ** & ** & ** & ** & ** & ** & ** & ** & ** \\
\hline \multicolumn{10}{|l|}{ Wrapping materials } \\
\hline Control $\left(\mathrm{W}_{0}\right)$ & 7.49 & 7.97 & 8.26 & 8.57 & 6.58 & 6.4 & 6.21 & 3.41 & 3.38 \\
\hline $\mathrm{WPP}\left(\mathrm{W}_{1}\right)$ & 7.57 & 8.2 & 8.51 & 8.77 & 6.72 & 6.56 & 6.39 & 3.54 & 3.49 \\
\hline $\mathrm{WNP}\left(\mathrm{W}_{2}\right)$ & 7.66 & 8.5 & 8.84 & 9.12 & 6.95 & 6.74 & 6.52 & 3.65 & 3.6 \\
\hline $\mathrm{BPP}\left(\mathrm{W}_{3}\right)$ & 7.57 & 8.22 & 8.57 & 8.79 & 6.72 & 6.62 & 6.41 & 3.54 & 3.5 \\
\hline $\mathrm{BNP}\left(\mathrm{W}_{4}\right)$ & 7.7 & 8.52 & 8.82 & 9.15 & 6.95 & 6.74 & 6.53 & 3.66 & 3.61 \\
\hline $\operatorname{LSD}_{(0.05)}$ & 0.04 & 0.0007 & 0.089 & 0.0007 & 0.061 & 0.061 & 0.0007 & 0.0007 & 0.0007 \\
\hline Level of significance & ** & ** & ** & ** & $* *$ & $* *$ & $* *$ & $* *$ & $* *$ \\
\hline $\begin{array}{l}* *=\text { Significant at } 0.01 \text { le } \\
\text { Stage } 1\left(S_{1}\right)=\text { Green but } \mathrm{f} \\
\text { Stage } 2\left(S_{2}\right)=\text { Greenish } \mathrm{w} \\
\text { Stage } 3\left(S_{3}\right)=\text { Ripe yellow }\end{array}$ & $\begin{array}{l}\text { dlly matu } \\
\text { aite fruit } \\
\text { ish green }\end{array}$ & $\begin{array}{l}\text { ed fruit } \\
\text { vith medi } \\
\text { fruit with }\end{array}$ & $\begin{array}{l}\text { with hard } 1 \\
\text { ium hard } 1 \\
\text { crispy pu }\end{array}$ & $\begin{array}{ll}\text { pulp } & \mathrm{W}_{0}= \\
\text { oulp } & \mathrm{W} 2= \\
\text { lp } & \mathrm{W}_{3}= \\
& \mathrm{W} 4=\end{array}$ & $\begin{array}{l}=\text { Control } \\
=\text { Non-per } \\
=\text { Perforate } \\
=\text { Non-per }\end{array}$ & $\begin{array}{l}W_{1}=\text { Perf } \\
\text { rforated } w \\
\text { ed black } \mathrm{p} \\
\text { rforated } \mathrm{bl}\end{array}$ & $\begin{array}{l}\text { forated wh } \\
\text { hite polyt } \\
\text { olythene } \mathrm{t} \\
\text { lack polytl }\end{array}$ & $\begin{array}{l}\text { iite polyth } \\
\text { hene bag } \\
\text { bag } \\
\text { hene bag }\end{array}$ & ne bag \\
\hline
\end{tabular}

The finding of the presented investigation indicated that total weight loss, sugar (reducing, non-reducing and total) and TSS of fruits were increased during storage under different treatments. At the same time, marketability of fruits was decreased but at stage 3 fruits when stored at $5^{\circ} \mathrm{C}$ and wrapped with black non-perforated polythene bag made possible to keep fruits in marketable condition for 36 days. The wider shelf life of treated guava was related to slower changes in chemical components. 


\section{REFERENCES}

Augustin, M. A., Osman, A. and Osman, A. 1988. Post-harvest storage of guava (Psidium guajava L., cultivar Taiwan). Pertanika, 11(1): 45-50.

Combrink, J. C., Kock, S. D., CJ-Van, E., De-kock, S. L. and Van-Eden, C. J. 1990. Effect of postharvest treatment and packing on the keeping quality of fresh guava fruit. Acta Hort., 275: 639-645.

Dutta, P., Banik, A. K., Raychoudhury, R. and Dhua, R. S. 1991. Influence of ethylene absorbents on shelf life of guava fruits. Indian J. Hort., 48(3): 213-216.

Gomez, K. A. and Gomez, A. A. 1984. Statistical Procedures for Agricultural Research. ( $2^{\text {nd }}$ ed.). International Rice Research Institute, Manila, Philippines. pp. 188-198.

Martinez, B. E., Guevara, G. C., Contreras, M. J. and Rodriguez, R. 1997. Preservation of guava at different storage condition. Acta Hort., 455: 747-754.

Medlicott, A. P., Sigrist, J. M. M. and Sy, O. 1990. Ripening of guava following lowtemperature storage. J. Amer. Soc. Hort. Sci., 115(3): 430-434.

Millar, C. D. and Bazore K. 1945. Guava. Hawaii Agr. Exp. Sta. Bull., 96.

Nag, A. R. 1998. Physico-chemical changes of four guava cultivars during different stages of ripening. M. S. Theis, Dept. Horticulture, BAU, Mymensingh. 75 p.

Oosthuyse, S. A. 1997. Effect of waxing and of a number of waxes on weight loss, shelf life and fruit quality of mangoes after four weeks of cool storage. Yearbook-South African Mango Grower's Assoc., 17: 105-110.

Phandis, N. A. 1970. Physico-chemical composition of guava fruits. Indian J. Hort., 27: 417-433.

Ramchandra and Chandra, R. 1995. Bio-chemical changes during maturity and storage in guava fruits. Indian J. Hill Farming, 8(1): 16-21.

Tsuda, T., Chachin, K. and Ueda, Y. 1999. Studies on keeping quality of guava fruit of Philippines. J. Japan Soc. Hort. Sci., 68(3): 669-674. 